\title{
Review of Nur Amali Ibrahim, Improvisational Islam: Indonesian Youth in a Time of Possibility.
}

\author{
Faizah Zakaria ${ }^{1}$ \\ Published online: 2 July 2019 \\ (C) The Author(s) 2019
}

Keywords Indonesia $\cdot$ Religion · Islam $\cdot$ Everyday $\cdot$ Conservative $\cdot$ Liberal $\cdot$ Moderate $\cdot$ Anthropology Youth

Indonesia is significant in the discourse on "moderate Muslims" as a nation noted for historically practicing the religion in a way that is tolerant of pluralism and emblematic of moderation. In recent years, that view has been challenged by an apparent conservative turn. Nur Amali Ibrahim's Improvisational Islam blurs the boundary between conservative and moderate, pushing back against the idea of a unique body of Indonesian moderate Muslims in a lively and provocative way. The book presents religious creativity and play as an analytical window into a bifurcated community of Indonesian Muslim youths that self-identify as activists of what they perceive to be a 'right' interpretation of Islam but whose everyday actions fragment into a bewildering mass of inconsistencies. The titular concept in this book is defined as unconventional forms of religious practices that mark attempts to reconcile religious and secular liberal values. Since the end of former President Suharto's harsh authoritarian rule in 1998, Islam - which had been politically repressed since the 1960 s - returns to political stage as part of a larger Indonesian democratic turn that Ibrahim dubs as "a time of possibility," intersecting with the youths' time of growth. While scholars of Indonesia have largely examined this re-energizing of Islam as a political force through party politics or social movements, Ibrahim seeks to access the quotidian experience of socializing and being socialized into self-identified Islamists or liberals through the lives of activists in autodidactic student organizations in universities. Specifically, he focuses on two groups: an Islamist organization, the Campus Proselytization Association, operating in Indonesia's top secular university, Universitas Indonesia and a

Faizah Zakaria

f.binte.zakaria@iias.nl

1 International Institute for Asian Studies, Leiden University, Rapenburg 59, 2311 GJ Leiden, the Netherlands 
liberal Muslim group known by its acronym Formaci, active in the top Islamic university in the country, Universitas Indonesia Nasional Syarif Hidayatullah.

The Islam that emerges, he writes, "is tentative, experimental and spills into multiple domains of social life...[but] are also implicated in the contests to define who is the most Muslim of all" (p. 17). While there are formal links between these student associations and party politics, the mode of tutelage was largely bereft of formal authority and took place mostly between students and seniors who were only slightly older. This gave the students greater room for self-directed learning; an opportunity that was fully appreciated as Formaci students who were mainly from Islamic junior schools began approaching the religion from Western sociological and historical perspectives while those from the Campus Proselytization Association had previously attended secular schools and now sought to deepen their understanding of Islamic traditional knowledge chains. This appetite for change through youthful learning harks back to Indonesia's birth as a nation-state, remembered through past generations of youths who had played a pivotal role in it, commemorated by the years of their politicization. If the generation of ' 45 legendarily fought for Indonesia's independence and the generation of ' 66 stemmed communist influence, this millennial generation were anxious to shape the brand of Islam that would prevail in their nation. The historical shadow implicates the debates of these youths over Islam in the shaping of their nation-state.

The tools for that shaping comes from present day global intellectual networks. Their adoption of these new ideas ruptures easy dichotomies, notably between Islamist and liberal as well as secular and religious. Each chapter features a central motif that embodies the unexpected, quirky outcomes of these engagements. We meet in succession: an Islamist man inspired by self-help guru Tony Robbins to walk on broken glass to build his faith in God, a homophobic youth who offers penis enlargement massages, a group wielding accounting books for a fair and transparent method to track their piety, an impious study circle that laughs at Islam in order to declare themselves the new religious authority, a preponderance of women activists in conservative rather than liberal Muslim groups and a member of an Islamist vigilante group, the Islamic Defenders Front, appearing to eschew prayers in order to sell radical Islamist paraphernalia. Economics and modern bureaucracy run through each effort to cultivate faith, a characteristic that Ibrahim argues makes the religious improvisation of their everyday comparable to the friction generated by global-local encounters in the reproduction of capitalism that Tsing (2005) had unpacked. Religious improvisation, thus, is different from the syncretism or mysticism that had historically marked Indonesian Islam as different. Improvisation builds for the future using tools perceived as modern, rather than relying on the past. This practice of religion thus cannot exist without the secular.

Ibrahim's fresh approach rises to a critique made by Anugrah (2015) by pointedly seeking not to reify a "moderate-progressive versus conservative-fundamentalism view of Indonesian Islam" and to take the realities of the political economy into consideration examining religion. Readers of the book might wonder at this point, though - is this rotating cast of odd characters representative of Indonesian youths as whole? The book's narrative strategy of dipping into strangeness to disrupt pre-conceived binary categories and the study's designed focus on the people who swim against the dominant religious currents in their respective institutions may have the effect of suggesting that its arguments are based on outliers. However, in arguing that we should allow ourselves to be, as he expresses it, "surprised by Islam," Ibrahim is not targeting the spectacular. 
Rather, the ethnography catches ephemeral moments in the stream of the everyday to suggest that this is the texture of the ordinary, where secular and religious cannot be disentangled. The Muslim youths that appear in Ibrahim's study do not make dramatic flourishes. The improvisations in which they are engaged are almost banal and may slip below notice. But, the book argues, if we take the banal impious innovations among Indonesian liberal youths seriously as a religious act and juxtapose them with the inventiveness of sober Islamist adherents who adopt secular bureaucratic techniques to return to a purer practice of religion, the two groups become symmetric mirror images.

It is for this reason that the concluding chapter makes a case that religious improvisation cuts across political self-identification and that this aspect is often missed when the focus of the discourse is on the binary between historical moderation and incipient fundamentalism or as the book puts it, between "moderate Indonesian and Indonistan" (p.125). This is in line with a critique of the distinction made between good Muslims and bad Muslims, which Mamdani (2004) locates as product of the geopolitics of the American war on terror. But even in a Muslim majority society distant from the main sites of conflict, Ibrahim emphasizes, this dichotomy finds purchase. Analyzing the polarization between Islamists and liberal Muslims through protests against legal measures to impose religious values such as the anti-pornography bill of 2008 , he draws attention to the inability of both sides to see themselves in the other even though they are inveigled in the same geopolitical conditions that necessitate improvisation. Religio-political differences have obscured the common everyday project of improvisation and in that obscuring, the violence of the neoliberal capitalism becomes masked. "The term [improvisational Islam] may seem redundant," Ibrahim observes, "given that all religious life is in some senses improvisational...how else could religion have a successful career in human history? In the case of Islam in the contemporary world, however, calling attention to the religious improvisation of its adherents is not redundant: it is political" (p. 150). Improvisational Islam concludes with a note of deep skepticism about the uniqueness of Indonesian Islam, not because it follows the tune of Islam as practiced in the Middle East, but due to the way it dances to the beat of the same geopolitical drum that accompany and politicize religious practices in the rest of the world.

It is perhaps a pity that the book ends here because it leaves unexplored the question of whether the act of improvisation can itself exert political force and if so, how. With national elections in Indonesia coming up in 2019, political parties and candidates seek to promote Islam in their platform as the 'right' form of Islam. For instance, Ma'ruf Amin, the running mate of Indonesia's incumbent president and the current chairman of the country's national religious council, is using "Islam Wasatiyyah" ("Middle Path Islam") as a rallying call. Such a vision is necessarily hegemonic; it promotes one proper way for the nation. Can improvisational Islam, dispersed in practice and divided in approaches, change anything beyond the everyday lives of adherents to the faith? Or is it purely a reactive rather than a pro-active mode of practicing religion? Moreover, at the level of international politics, anti-Islam activists who influentially argue that the peaceful majority of Muslims are irrelevant in the fight against what they perceived as Islamic violence might question whether creative Muslims matter. The book makes a solid case that the flexibility of everyday Islam often slips through the spaces of state control even though it is itself a product of global politics. But it remains unclear to what extent it can be a force for social or political change within Indonesia and beyond. 
The arguments presented in this book provides an excellent place to start a classroom discussion, especially when placed against academic configurations of Indonesian or Southeast Asian Islam that highlight exceptional moderation such as 'Islam Nusantara' (Azra 2002). The unexplored potential of 'improvisational Islam' as an analytical category with political heft does not detract from the core insight of this fine study: that transient practices of everyday Islam are not only universal but also resilient. What it adds to the ongoing debate over the 'moderate Muslim' label is a needed reminder not to let the capital ' $\mathrm{M}$ ' in Muslim dictate the direction of inquiry into a Muslim society by consigning all actions to a perceived Islamic norm. In so doing, it moves the debate away from the question of what those norms are to what they can be made into. Religious play, by its nature, is made to be remade. With that creativity comes the possibility of new worlds, new times, from directions least expected.

Open Access This article is distributed under the terms of the Creative Commons Attribution 4.0 International License (http://creativecommons.org/licenses/by/4.0/), which permits unrestricted use, distribution, and reproduction in any medium, provided you give appropriate credit to the original author(s) and the source, provide a link to the Creative Commons license, and indicate if changes were made.

\section{References}

Anugrah, I. (2015). Recent studies on Indonesian Islam: A sign of intellectual exhaustion? Indonesia, 100, $106-115$.

Azra, A. (2002). Islam Nusantara: Jaringan Lokal dan Global. Bandung: Mizan Media Utama, 2002.

Mamdani, M. (2004). Good Muslims, bad Muslims: America, the cold war and the roots of terror. New York: Pantheon Books.

Tsing, A. (2005). Friction: An ethnography of global connection. Princeton: Princeton University Press.

Publisher's note Springer Nature remains neutral with regard to jurisdictional claims in published maps and institutional affiliations. 